\title{
A Study on Work Family Balance and Challenges Faced By Working Women
}

\author{
Mr G.Shiva \\ Assistant Professor Department of Commerce Rathinam college of Arts and science Coimbatore Tamilnadu \\ INDIA
}

\begin{abstract}
Work-life balance is the term used to describe practices in achieving a balance between the demands of employees family and work lives. The demands and pressures of work make difficult to stretch time for balancing work-life activities. Women taking up work life balance challenge have an impact on women's advancement. Organization also may create work place culture and climates that reflect concern for employees' lives outside of work. It is important for organizations to periodically review current work processes and practices to determine which ones lead to work in efficiencies and employee stress. In this background the present study was undertaken to determine the work-life balance and challenges faced by working women. The sample consists of 200 career women working in Kerala, India. The questionnaire was collected from respondent .After analyzing by using various tools like percentage analysis, chi-square and correlation, results show that there is a work-family conflict and lack of organizational satisfaction among working women.
\end{abstract}

Key words: Work life balance, career growth, organizational satisfaction

\subsection{Introduction}

\section{Introduction And Methodolody}

The need for balancing work-family of working women is very important. In olden days man was considered as breadwinner and women was consider as home maker but today everything was changed .Both men and women have equal responsibility in work and family. In order to balances work and family the women have to plan their career effectively. The good work-family balances includes the priorities fixing by working women, awareness of current working position and environment, update latest technology, fix schedule such a manner that sufficient time with family, monitoring self performance and improve the area when and where required.

\subsection{Statement Of The Problem}

Major parts of Indian women are allowed to work; still they face some problems in workplace and family. The problems faced in their work place are Indian working women do not get the respect from their male colleagues in the workplace. In case of married working women is they are not allowed by family members to go for business tour. Gender discrimination is another problem faced by women in case of pay. In some companies women employees are paid less salary than men. Even women professional are in high position in their office, they have to return from office in correct time, cook, clean and look after their family affairs. This makes them more stress and leads to some health problems. Another most difficult problem faced by working women who have small children is they forced to leave their child in daycare or in hands maid on whom they have little faith. This creates more tension in them and less concentrate on their work. Although working women hired maid to do their household work they have to give more pay. Working women are not able to attend family function due to lack of leave and also not able to give proper care to family members. This research is to find out more challenges faced by working women.

\subsection{Objectives Of The Study}

- To study about hindrances faced by working women in their career development

- To study about how working women balance their work and family.

- To know about their organizational satisfaction.

\subsection{HYPOTHESIS}

$\mathrm{H}_{0}$ : There is no work-family conflict between working women

$\mathrm{H}_{1}$ : There is work-family conflict between working women 


\subsection{Scope Of The Study}

This study is undertaken in various private and public sector includes banks, educational institutions and companies with the purpose to gather more details about work and family balances by working women. This research helps the organization to formulate the future plans and policies for working women.

\subsection{Methodology}

\subsubsection{Primary data}

The questionnaire was given to 200 samples. Data was collected from 200 women working of private and public sector including schools, hospital, colleges and also other companies. Non probabilities sampling techniques was used. The various tests like percentage analysis, correlation, weighted average method. Questionnaire was used to collect the details from working women. In questionnaire question include profile details, work-family conflict details, and organizational satisfaction details.

\subsubsection{Secondary data}

Reviews 's were collected from various journals, magazines like Journal of Applied Psychology, Journal of Human Resources, Journal of Occupational Health Psychology, Journal of Social Psychology, European Journal of Business \& Management. The model used for study is conceptual model

\subsection{Limitations Of The Study}

- The study is focused only to literate working women

- The duration of project is very short period.

\subsection{CHAPTER SCHEME}

Chapter 1: Introduction and Methodology

Chapter 2: Review of Literature

Chapter 3: Profile of Working Women

Chapter 4: Analysis and Interpretation

Chapter5: Finding and Suggestions

Chapter6: Conclusion

\subsection{Introduction}

\section{Review Of Literature}

The aim of this chapter is to review the already available literature relating to my present study. Main purpose is to evaluate how women balance their work and family. Therefore the factors affecting the workfamily balances and problems faced by working women is evaluated with the help of already existing literature. This chapter includes various opinions of different authors and their research finding.

\subsection{Reviews}

PatriceM.Buzzanell,RebeccaMeisenbach,Robyn,RemkaMeinaLiu,VenessaBowers\&Ciny Conna examines women who held in different positions includes managers, vice presidents, circulation managers and also human experts They mainly focus on managers working experience and how work-life concerns upon their return to paid work following maternity leaves. They found that all participants change from good mother image into a good working mother role that fit their lifestyles and interests. To accomplish this reframing, participants engaged in three supportive factors of the good working mother image (a) good working mothers arrange quality child care (b) good working mothers are (un) equal partners and (c) good working mothers feel pleasure in their working mother role. Because of these factors enable participants to make sense of and establish the worth of working motherhood to family members, friends, acquaintances, organizational members, and community members and working women also provide a reason why middle or upper-class working and stay-athome mothers may be in conflict about work and family choices.

\subsection{FINDINGS}

\section{Findings And Suggestions}

\subsubsection{Percentage Analysis}

- Majority of working women under the age group of 25-35 years

- $83 \%$ of working women were married and remaining unmarried. Out of $83 \% 75.5 \%$ of them have children.

- The working women belongs to nuclear family were $67 \%$

- $30.7 \%$ of Married Women having satisfaction to spend time to read, magazines and newspaper etc.

- Women working in public sector having more organization satisfaction than private sector. 
- The leading cause of stress arises because of communication with superior.

- $18 \%$ of respondents having salary above 20000 having servant in their home.

- $60 \%$ of the respondents completed graduation

- $58 \%$ of the respondents having ability to balances work and family.

- $39 \%$ of women having working experiences of 1-3 year.

- $43.5 \%$ of women spend half an hour for travelling.

- Majority of working women having pay scale of 5000-10000.

- $57 \%$ of working women manage stress by involving in various entertainment activities.

- Only $13 \%$ of respondents highly satisfied to cancel plan with spouses or parents when they have to work late.

- Among 200 respondents only $17 \%$ having satisfaction to make spouses/parents to accept job demand.

- Only $7 \%$ of respondents strongly agree that they talk up to superior when they deserve promotion.

- $9.5 \%$ of respondents accept any type of job.

\subsubsection{Weighted Average Method.}

- Organization satisfaction factor provides job performance award have more priority.

- According to weighted average method the work-family conflict factor spend time dependent have more priority.

\subsubsection{Correlation Analysis}

- There was significant relationship between working hours and stress.

- There was no significant relationship between working hours and time spend on reading magazines and newspapers.

\subsubsection{Chi-Square Analysis}

- There was no association between training provided and ability to balance work and family.

\subsection{Suggestions.}

Counsellor should be appointed by Organization for understanding more about problems of Working Women. Administrators need to create a climate where employees do not fear bringing up a family. Managers can provide a supportive environment that permits flexibility in schedules, telecommuting options, personal time off, onsite child care, and other family-focused program. Internal social network (forum, blog, mentor, coaches) for working parents. Wellness/resource room (for meditation, prayer, back-up child care Thus, organizations need to formulate guidelines for the management of WFCs since they are related to job satisfaction and performance of the employees. Further the research should be conducted on illiterate people. Additional research is also needed to compare the both men and women because experiences may be differ with regard to work and family balances and also helps to find out more consequences of work and family conflict. In order to attain in-depth understanding of one's work and family life, researchers has to study multiple perspectives such as job stress, quality of life, mental health and work demand

\section{Conclusion}

The problems are faced not only by the lower level of the employees but also higher level. The research I have reviewed in this report provides an empirical justification for innovative policy development includes long work hours and work-life conflict. The overall conclusion is that long-term exposure of workers to excessive work hours and high levels of work-to-family interference elevates their risk of mental and physical health problems. Moreover, it is clear from the research that solutions to these potential problems must address workload and job demands, employee choice and flexibility in work hours and arrangements, organizational cultures, and the behaviors' of managers at all levels. From this research it is understand that women faced several challenges to balances work and family. Both private and public sector has to reframe the policies in order to balances family and life

\section{Bibliography}

[1]. Anil Dutta Mishra(1994).Problems \& Prospects of Working Women in Urban India. Mittal Publications, 1994 - 139 pages

[2]. Anderson, A. K. (2005). Affective influences on the attentional dynamics supporting awareness. Journal of Experimental Psychology: General, 154, 258-281. doi:10.1037/0096-3445.134.2.258

[3]. Ramanna A,Bombawale U(1984).Transitory status images of working women in modern India.Indian J Social Work.

[4]. Donald Copper,Pamela Schindler.(2003)Business Research Method.The M Graw-Hill Irwin Series in Operations\&Decision Sciences Business Statistic, McGraw-Hill Education, 12,

[5]. Frone, M. R. (2003). Work-family balance. In J. C. Quick \& L. E. Tetric

[6]. (Eds.). Handbook of occupational health psychology (pp. 143-162). Washington, DC: 
[7]. American Psychological Association.

[8]. R.Pannerselvam(2004)Research Methodolody.:Prentic Hall of India Private Limited, New Delhi ISBN 81.203-2452-8

[9]. R.Nandagopal,K.Arul Rajan,N Vivek.(2008)Research Methods in Business.Excel books.ISBN 81-7446-528-6

[10]. Work-Family Balances Retrieved from http://en.wikipedia.org/wiki/Work\%E2\%80\%93life balanc

[11]. Susan M.Heathfiel .Work-Family Balances Retrieved from http://humanresources.about.com/od/glossaryw/g/balance.htm 